\title{
ArcheoSciences
}

Revue d'archéométrie

33 (suppl.) | 2009

Mémoire du sol, espace des hommes

\section{Urban archaeology and environmental data: the Lyon experience}

\section{S. Gaillot and E. Hofmann}

\section{(2) OpenEdition \\ 1 Journals}

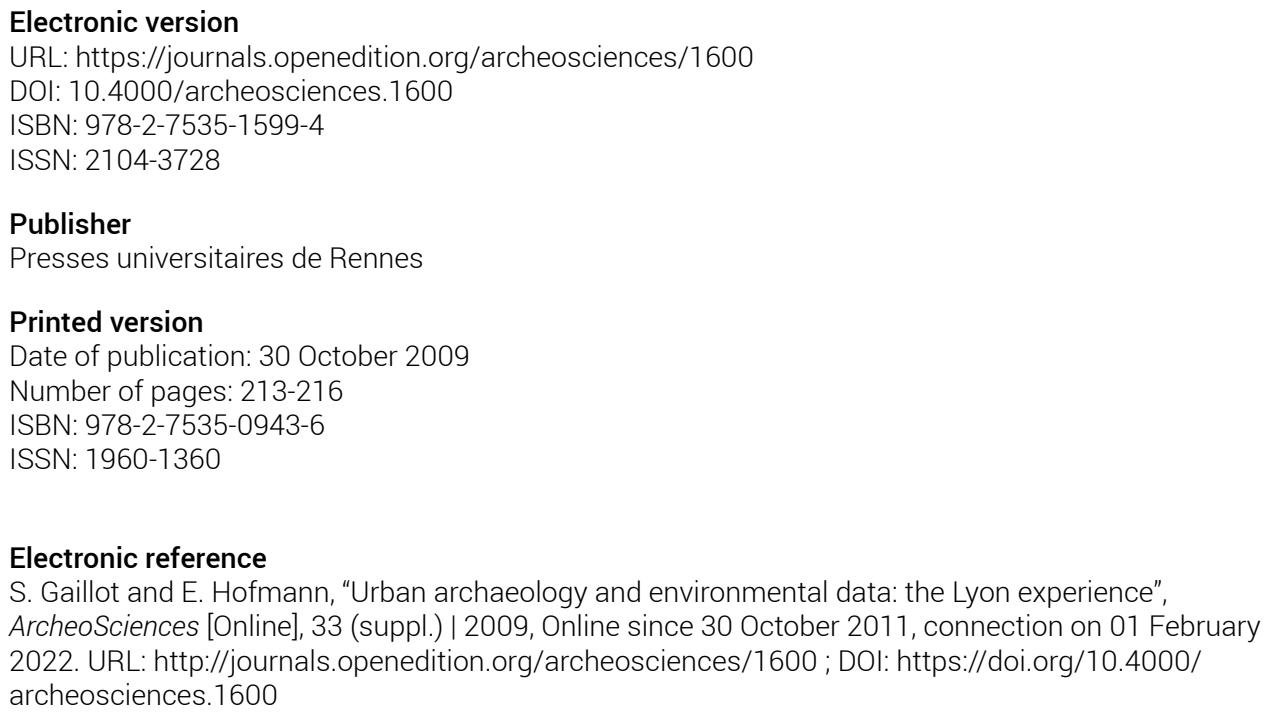




\title{
Urban archaeology and environmental data: the Lyon experience
}

\author{
S. Gaillot* and E. Hofmann*
}

Key words: Urban Archaeology, Geomorphology, Environnement, Lyon, GIS.

Restricted to the perimeter of Lyon, the City Archaeological Service has developed an adapted methodology to better exploit geoarcheological data in the context of a completely urbanized area.

\section{GENERAL CHARACTERISTICS OF GEOARCHEOLOGICAL PRACTICES IN URBAN AREAS}

Considering environmental factors in the understanding of the shape, function, and even disappearance of archaeological remains, geoarchaeology is submitted to the following constraints in urban environments:

- quasi-complete disappearance of the "natural" landscape, which is, for geoarchaeologists, a key element for understanding morphogenesis (Fig. 1c);

- destruction of most of the Holocene archives: no peat bog exists any longer in Lyon (even if they had existed in the district of Vaise before urbanisation). Stream channels are mostly canalised, and abandoned channels have been filled in. Only some limited sedimentary sequences still have potential for palynological analyses;

- land use regulations excluding from the delineated archaeological perimeter areas of high geoarchaeological interest, such as most of Lyon's eastern plain (Fig. 1b);
- degradation and restricted dimensions of zones where archaeological surveys are implemented;

- brevity of surveys when implementing preventive archaeology.

Nevertheless, these constraints are compensated by the large number of archaeological surveys (approximately one thousand have been conducted since the end of the 17 th century (Fig. 1b), i.e., about ten new surveys a year on average in recent years), and by the density of the archaeological vestiges, the eldest dating back to the Mesolithic.

\section{MethodS AND DEVELOPED TOOLS}

During studies, classical field methods are favoured (identification of lithological facies, grain-size analysis, radiocarbon dating, etc.). In some cases, more specific methods are used (magnetic susceptibility, CM image, palynological analyses, identification of malacofauna).

In order for environmental data to be better incorporated in the understanding of archaeological sites, three main strategic orientations have been selected, and two practical tools are being developed:

1. In 2008, the Archaeological Service hired a full-time geomorphologist and set up a scientific partnership with the Department of Geography, University Lyon 2, along

Service Archéologique de la ville de Lyon. (stephane.gaillot@mairie-lyon.fr) (etienne.hofmann@mairie-lyon.fr) 


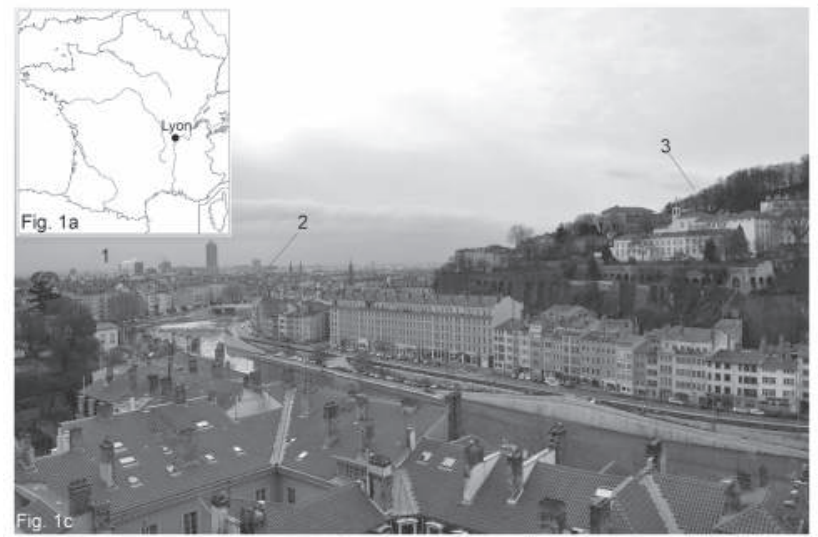

A completely urbanized place (view from Croix-Rousse hill)

1 : Presqu'tie

2: Sao̊ne river

3: Fourvière hill

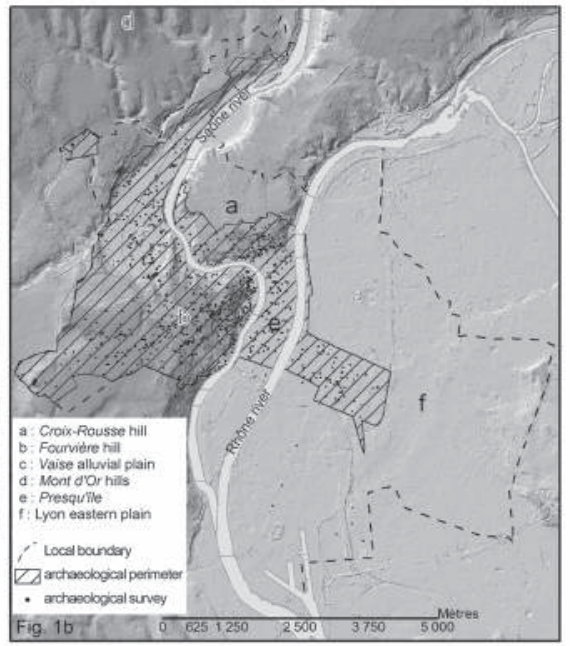

Figure 1: Location of studied sites at a national (1a) and regional level (1b). General view of Lyon (1c). with collaboration with specialists of local fauna and palynology.

2. A geomorphological database, complementing the archaeological database ALyAS, is being developed. Its objectives are the qualification and georeferencing of all natural layers, associating the facies of deposits (1), processes of deposition (2), and landforms (3). It is being complemented with a thesaurus of landforms (alluvial plains [Fig. 2], hillslopes, etc.).

3. Litho-archives, which are under development cover a wide regional spectrum, including cohesive rocks (crystalline, volcanic, sedimentary, sampled in local outcrops and in ancient buildings), soft rocks and superficial deposits (alterites, till, alluvium, colluvium, soils, etc.). Samples are georeferenced in the geomorphological database.

\section{Four CASE STUDIES}

\section{1- Alluvial plain of the Rhône river (Guillotière district,} Bernot et al., 2009)

The site of the future Sergent Blandan Park is located in the alluvial plain, on the left bank of the Rhône river (Fig. 3a). The use of an accurate DTM, the detailed study of ancient maps (18th century), and geotechnical surveys (boreholes) suggest the existence of two geographical units, of different ages and with different geoarcheological attributes:

- fluvio-glacial butte, topped with red soil, constituting a remnant of the Villeurbanne terrace; artifacts date back to c. 18,000 BP, i.e., the upper Palaeolithic);

- lower area, possibly a channel of the Rhône river, active over a period of 13,000 years, that is, between $18,000 \mathrm{BP}$
(Upper Palaeolithic), and 5000 BP (Late Atlantic-Subboreal, i.e., end of the Middle Neolithic).

\section{2- Alluvial plain of the Saône river (Vaise district - Monin} et al., 2008)

The site under construction located at 4-6 Mont d'Or St., in the Vaise alluvial plain, on the right bank of the Saone river, gave a detailed record of alluvial levels. The underlined words in this paragraph are defined in the archaeological and geomorphological thesaurus. The stratigraphy displays deposits of the Saône river channel. River environments changed from wetlands (lacustrine andlor palustrine areas) to active floodplain topped with soils. The site was occupied during the transition from the Early to the Late Iron Age, but was still flooded at that time. Layers of fresh deposits are present in soils, embankments (remblais) and levels of occupation since the first phase of occupation, then in the Late Iron Age, during Antiquity (first half of the 1st century AD), and in modern times (layers deposited during the floods of 1856) - Fig. 3b.

3- Croix-Rousse platean (so-called "fish bone" galleries) (Bernot et al., 2008)

A network of galleries $1.4 \mathrm{~km}$ long, featuring a peculiar "fish bone" architecture, has been explored in Lyon (district of Croix-Rousse). It connected the summit of the plateau with the alluvial plain of the Rhône at the bottom. A comparison of the limestones from our litho-archives and from the rubble collected from the gallery walls, permitted two origins to be suggested for the building:

- the Mont d'Or hills, north of Lyon: "Couzon" stone was used in Lyon only after the Renewal period; 


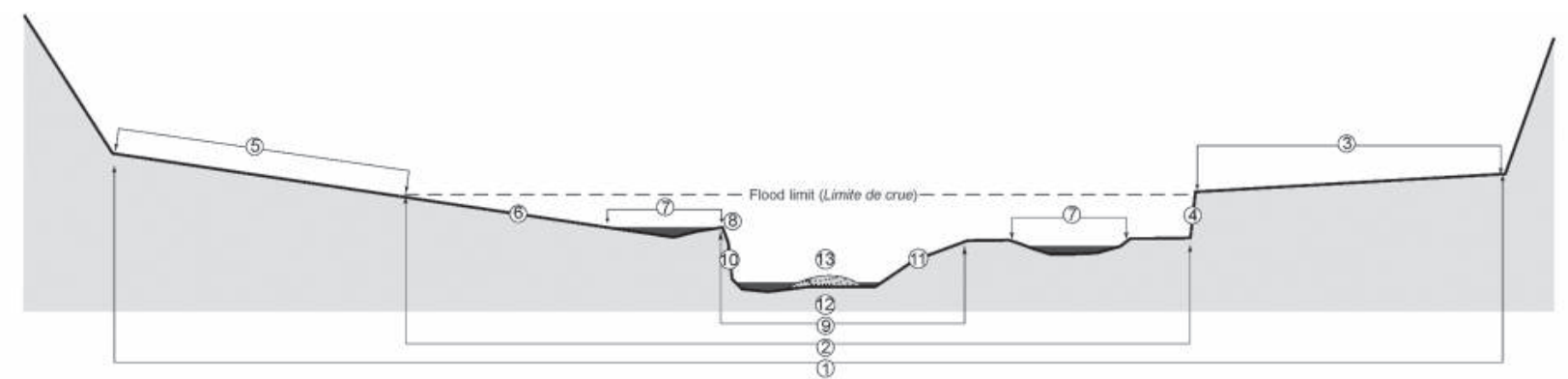

(1) Fluvial plain (plaine fluviale) : zone plane limitée par des éminences majeures (terrasses)

(2) Active fluvial plain (plaine fluviale active) : plaine fluviale au sens strict ou "lit majeur" ; surface maximum recouverte au moment des crues et partie du cours d'eau où les débordements entrainent une emprunte morphologique.

(3) Fluvial terrace (terrasse fluviale) : fragment résiduel d'une ancienne plaine alluviale retouchée par l'érosion puis mise en relief par l'incision du cours d'eau.

(4) Fluvial terrace slope (talus de terrasse fiuviale) : abrupt topographique marquant l'extrèmité d'une terrasse fluviale.

(5) Fluvial ramp (glacis ffuviâ) : relief plan et peu incliné, lit abandonné qui se forme quand lincision d'un cours đ’eau est progressive et/ou que l'érosion latérale a sapé le talus qui limitait la terrasse fluviale

(6) Flood plain (plaine dinnondation) : plaine adjacente au chenal et formée par migration et/ou débordement de ses alluvions. Sa surface correspond à la zone d'épandage des débordements.

(7) Flood basin (bassin d"inondation): dépression marginale du chenal inondée lors des crues débordantes.

(8) Fluvial levee (levée fluviaie) : partie supérieure de la berge.

(9) Channel (chenaf) (forme d'érosion) : zone habituelle d’écoulement des eaux fluviales.

(19) Erosion bank (berge d'érosion) : (forme de sapement) : abrupt topographique formé par le sapement des eaux s'écoulant dans le chenal

(11) Construction bank (berge de construction) (forme de dépôt) : accumulation formée par la sédimentation des alluvions transportées par l'eau sur les bords du chenal

12. Channel bottom (fond de chenal) (forme de dépót) : peut correspondre à un seuil ou à une mouille

13 Channel bank (banc de chenaf) (forme de dépôt) : accumulation formée dans le fond du chenal par la sédimentation des alluvions transportées par l'eau (banc de galets, banc de sable)

Figure 2: Thesaurus of fluvial forms.
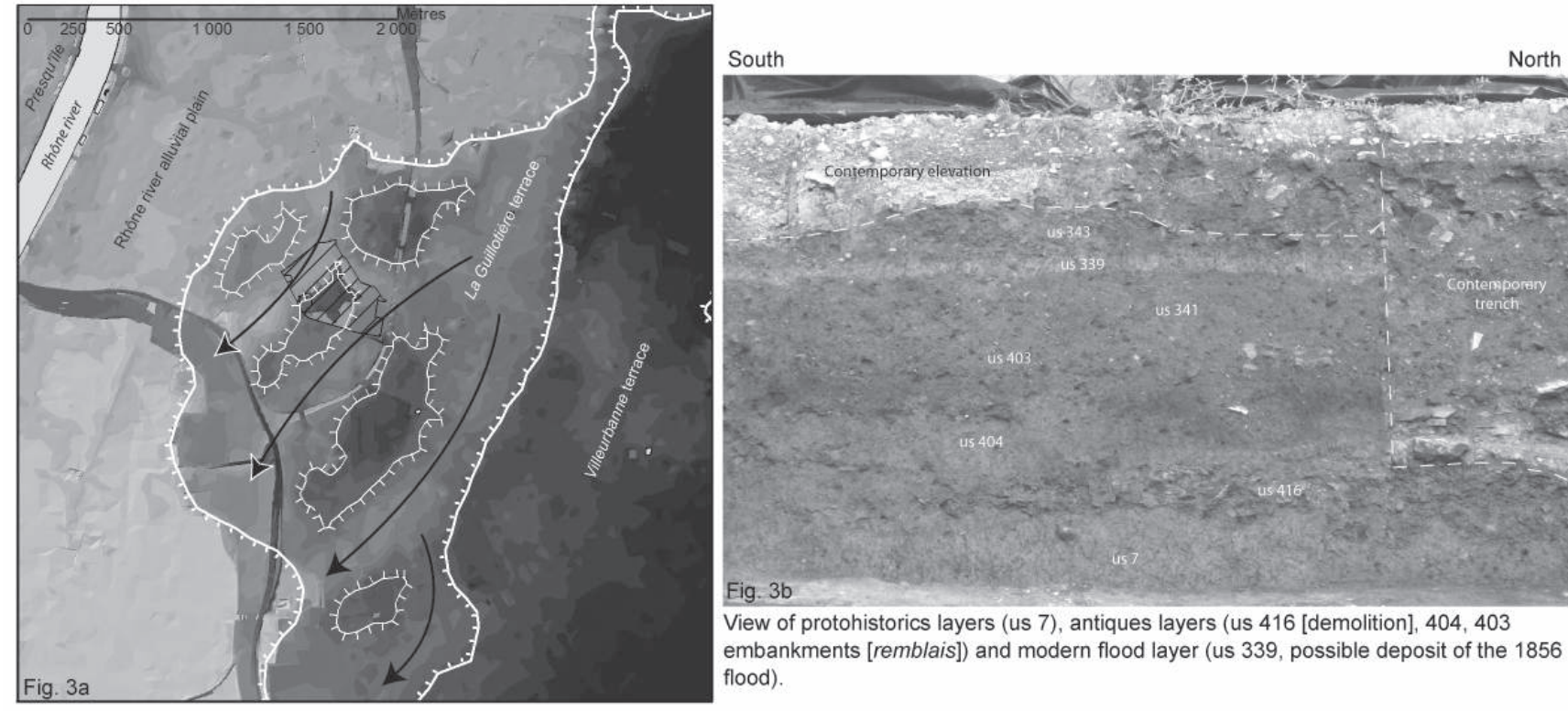

View of protohistorics layers (us 7), antiques layers (us 416 [demolition], 404, 403

embankments [remblais]) and modern flood layer (us 339, possible deposit of the 1856 flood).

\footnotetext{
$\nabla$ Archaeological survey

Topographic limits of landforms

Abandoned channels of the Rhône river (?)
}

Figure 3: Two case studies: alluvial plain of the Rhône river, Sergent Blandan park, 2009 (Fig. 3a); alluvial plain of the Saône river,4-6 Mont d'Or St., 2008 (Fig. 3b) 
- quarries in the Mâcon hills (right bank of the Saône river), approximately $70 \mathrm{~km}$ upstream from Lyon.

The construction of the "fish bones" network may be related to the royal citadel of Lyon, which was built in 1564 on the Croix-Rousse plateau, following the order of King Charles IX, and was dismantled in 1585 by request and to the expenditure of the city of Lyon.

\section{4- Fourvière plateau (Antiquaille)- Hofmann et al, 2008}

The archaeological diagnosis of the Antiquaille site, which is built on the slope of the Fourvière plateau, below the Roman theatre and odeon, established that the present topography has few points in common with what it was in Antiquity:

- in the area occupied by the Roman city from the first phases of its construction, the archaeological approach has revealed a set of anthropic stepped terraces on a slope that has become entirely smooth over the following centuries;

- geomorphological study, based on the identification of superficial deposits (till, loess and lehm, which is a pedological cover developed on the top of loess), revealed a NorthSouth vale pre-dating urbanization. The soils of this vale and their local reworking, induced by the construction of buildings and the occupation of adjacent land during Antiquity, could be studied. Understanding the impact of antique urbanization on the original topography is rare in urban archaeology.

\section{References}

Bernot, E., Ducourthial, C., Dessaint, Ph. and Gaillot, S., 2008. Rénovation lourde du tunnel de la Croix-Rousse - 69001/69004 Lyon, Le réseau souterrain des "arêtes de poisson”, Rapport de diagnostic d'archéologie préventive déposé au Service Régional de l'Archéologie Rhône-Alpes, Lyon.

Bernot, E., Ducourthial, C., Dessaint, Ph., Gaillot, S., Le Mer, A.-C., Leroy, E. and Mani, C., 2009. Aménagement du parc Blandan, 69009 Lyon, Note préliminaire, service archéologique de la ville de Lyon, Direction des affaires culturelles.

Hofmann, E., Baldi, J.-S., Mège, C., Dessaint, P., Gaillot, S., Chamoux, C., Ikhlef, M., Strippoli, L., Argant, T., Bertrand, E., Carrara, S. and Fellague, D., 2008. 1 rue de l'Antiquaille, 69005 Lyon, Rapport de Diagnostic Archéologique Préalable à la réalisation des bâtiments C, D, G., Rapport déposé au Service Régional de l'Archéologie Rhône-Alpes, Lyon.

Monin, M., Carrara, S., Gaillot, S., , Bertrand, E., Bouvard, E., Mege, C., Clement, B., Dessaint, P., Foucault, M., Hofmann, E. and Pereira, P., 2008. 4-6 rue du mont d'Or, 69009 Lyon, Rapport de diagnostic d'archéologie préventive déposé au Service Régional de l'Archéologie Rhône-Alpes, Lyon. 